\title{
A Review of Issues on Water Quality Arising from a Florida Court Case on EPA's Proposed Water Quality Standards and Its Implications on Water Quality Guidelines Beyond the State of Florida
}

\author{
Kenneth G. Oertel \\ Law Firm of Oertel, Fernandez, Bryant \& Atkinson, P.A., USA
}

Copyright $(2018$ by authors, all rights reserved. Authors agree that this article remains permanently open access under the terms of the Creative Commons Attribution License 4.0 International License

\begin{abstract}
In July 2008, the United States Environmental Protection Agency (EPA) was sued by an environmental public interest group, Earthjustice, over the manner in which Florida regulated nutrients through its water quality regulatory program. The suit accused EPA of being lax in allowing Florida to apply a water quality standard to control the discharge of nutrients into waters of the United States which was ineffective to achieve an adequate control of nutrients. The suit demanded that EPA take action to adapt and impose its own rule to control the discharge of nutrients in Florida. EPA decided not to defend itself in this lawsuit. Instead it issued a finding that a stronger, more stringent and objective water standard should be adopted for Florida. EPA settled the case with Earthjustice in August 2009 and entered into a consent decree with the Plaintiff which committed EPA to adopt numeric nutrient criteria for the State of Florida. EPA then, through its plenary powers under the Clean Water Act (CWA), proposed to adopt a numerical nutrient discharge regulation to supersede Florida's existing regulations. EPA's regulations were published in the Federal Register as a predicate to final adoption. EPA's action stimulated a host of legal challenges from the State of Florida itself and a large array of municipal, utility, industrial, agricultural and other interested entities. The litigation was heard in the U.S. District Court for the Northern District of Florida, and resulted in the bulk of EPA's proposed regulations being disallowed by that Court. The Court's decision was based upon a lack of a demonstrated relationship between EPA's proposed discharge concentrations and a negative response within the receiving waters. EPA failed to show its rule set the correct standards to prevent harm to the receiving waters. The Court's decision stands for the proposition that since the CWA stands for the protection of the "integrity" of the Nation's waters, limitations on discharges must be determined on what will actually cause
\end{abstract}

harm to the receiving waters.

Keywords Pollutant, Necessity Determination, Eutrophic, Oligotrophic, Biological Nutrient Removal, Clean Water Act

\section{Florida's Original Nutrient Rule}

Under the CWA, 22 U.S.C. 1251, et. seq., the individual states are given the responsibility to adopt and enforce water quality controls to "restore and maintain the chemical, physical and biological integrity of the Nation's waters." However, EPA retains the power to impose its own standards upon a state where EPA makes a finding that additional criteria are necessary.[4]

Florida's Water Quality Regulations are contained in its administrative code adopted by its Department of Environmental Protection. These regulations contain a host of standards which cover a large list of allowable tolerances and limitations for the discharge of pollutants into the air and waters of the state. At question in this article was Florida's regulation controlling the discharge of nutrients (Nitrogen and Phosphorus) into state waters. That rule, unlike most other of Florida's water quality regulations, did not contain an objective (numeric) limitation of such discharges but was a narrative requirement. The text of this regulation read as follows: In no case shall nutrient concentrations of a body of water be altered so as to cause an imbalance of natural populations of aquatic flora or fauna.

The suit against EPA by Earthjustice, which prompted EPA to decide to impose more severe numeric limits on the discharge of nutrients into state waters, was initiated in 
large part by widespread algae blooms which occurred in many of its waterbodies. Those algae blooms have been very detrimental to water quality, and have a severe effect on aquatic life. Massive fish kills caused by anaerobic conditions which accompany algae blooms are well documented.

In Florida, water quality standards are enforced statewide by the Department of Environmental Protection and Water Management Districts, which operate in several separate areas. Controls over the discharge of nutrients is normally exercised through the issuance of permits and accompanying conditions to those permits, which are required for any discharge into state waters.

The sources of nutrients which affect Florida's waters have been studied by various entities.[6][8] There is no general consensus as to the hierarchy of predominant sources. There is a general understanding that there are a number of factors which cause nutrient discharges. They include septic tanks, stormwater runoff, waste water treatment plants, industrial facilities, agricultural operations and atmospheric deposition. The discharge of nutrients from septic tanks is not regulated by the state and the control of discharges from agricultural operations is regulated only in designated areas.

There is also a natural process which contributes significant amounts of nutrient enrichment. That process is a result of soil decomposition. Much of the south and central Florida soils are of an organic nature; peat and muck. This is a result of the extensive occurrence of swamps and other inundated areas which existed in primeval Florida. Over time, areas of inundation build up peat deposits, which consist of partially decomposed aquatic vegetation. After thousands of years, swamps and shallow lakes can build up many feet of peaty soils. As long as these areas remain flooded or wet, the peat remains intact.

Starting around 1870-1880, large areas of Florida underwent drainage work, which continued for over a century. Networks of canals and other drainage conveyances were constructed, which significantly lowered the water table and exposed millions of acres of these organic soils to sunlight and the atmosphere. The effect of this causes oxidation of the peat. When that occurs, the nutrients bound up in that material are freed to drain into existing water bodies. This phenomenon can be controlled by carefully managing the water table, but the decay of such soils is continuous.[1]

When EPA was sued by Earthjustice, it deliberated whether to pre-empt Florida's rule for a more objective (numeric) standard to more strictly control the discharge of nutrients. On January 14, 2009, the EPA administrator issued a finding that Florida's Nutrient Rule did not adequately protect its waters under the Clean Water Act (Letter from Benjamin A. Grumbles, Assistant Administrator, U.S. Environmental Protection Agency, to Michael Sole, Secretary, Florida Department of
Environmental Protection, January 14, 2009).[13] That decision began EPA's formulation of standards it intended to impose as a substitute to Florida's narrative standard. Among other things, the 2009 determination stated:

Water quality degradation due to nutrient over-enrichment is a significant environmental issue in Florida. Florida's Department of Environmental Protection has acknowledged and documented the magnitude of over-enrichment. According to Florida's 2008 Integrated Report, approximately 1,000 miles of rivers and streams, 350,000 acres of lakes, and 900 square miles of estuaries are impaired for nutrients in the State. With almost 800,000 nutrient-related data points [in an available database], Florida has substantially more data points than any other State or Territory to clearly characterize the magnitude of its nutrient challenges.

EPA then undertook research into what would be appropriate limits for nutrient discharges in various geographic areas of the state and for different types of water bodies.[5][6][8] The method devised by EPA was to obtain data from a variety of "reference" water bodies which were believed to not suffer adverse effects from excess nutrient concentration. The data from these waterbodies, which were considered to be pristine, was used to formulate EPA's rule. EPA published several notices in the Federal Register soliciting comments from the public and affected entities.[3]

EPA's Proposed Water Quality Standards for the State of Florida's Lakes and Flowing Waters was published at 75 Fed. Reg. 75,762, on January 26, 2010.[5] Soon after EPA's initial publication of its proposed nutrient discharge standards, EPA began to receive an immense critical response from the State of Florida, local governments, agricultural interests, utilities and industrial entities.[2][11][12] Over 3,300 comment documents were submitted EPA expressing concern over the scientific and analytical approaches used to derive the criteria, the lack of demonstrated dose-response relationships between nutrients and biology, potentially massive costs to build or upgrade treatment systems, the possible inability of conventional technologies to achieve the required criteria, the manner in which the criteria will be enforced at the state level, and the legal precedent established by EPA in stepping in to promulgate water quality criteria for a state. Despite the barrage of critical comments submitted to EPA after the publication of these rules, EPA remained undeterred in its efforts to impose its drafted water quality standards upon the State of Florida. Consequently, when the group of objectors resigned themselves to the fact that EPA would not relent in or modify its efforts to have a final adoption of those water quality standards, a host of lawsuits opposing the rule were filed in U.S. District Court for the Northern District of Florida. 


\section{EPA's Rule}

The rule criteria determined by EPA covered five separate geographic areas of the state and contained different criteria for springs, lakes, and rivers. Without going into excessive detail on these categories, it is illustrative of the rule to describe the standards for total Phosphorus (TP) and total Nitrogen (TN) for the area described as Panhandle West. Those criteria were 0.820 $(\mathrm{mg} / \mathrm{l})$ for $\mathrm{TN}$ and $0.069(\mathrm{mg} / \mathrm{l})$ for $\mathrm{TP}$, for rivers/streams. For canals, $1.6(\mathrm{mg} / \mathrm{l})$ for TN and $0.042(\mathrm{mg} / \mathrm{l})$ for TP. For Clear Lakes, 1.00-1.81 (mg/l) for TN and 0.03-0.087 (mg/l) for TP.[4]

These criteria created a massive outcry from utilities which operated wastewater treatment plants, both publicly owned and private not-for-profit entities. These criteria were lower than some natural conditions in Florida's rivers and streams.[14]

According to an EPA publication, most wastewater treatment utilities utilize Biological Nutrient Removal (BNR) to remove nutrients from their treated water discharge. Generally speaking the best treatment process in use today can achieve treatment levels of $3.0(\mathrm{mg} / \mathrm{l})$ for $\mathrm{TN}$ and $1.0(\mathrm{mg} / \mathrm{l})$ for TP. See, Biological Nutrient Removal Processes and Costs, EPA Office of Water, EPA-823-R-07-002, June 2007.[7]

Part of EPA's rule adoption effort also included an estimate of regulatory costs the new water quality standards would require to attain compliance. For waste water utilities, EPA's estimate was over one hundred million dollars.[9] This figure was widely criticized as being grossly understated by that industry. Curiously, EPA's calculations were not based on the true cost of meeting the actual discharge limits, but only to achieve a higher level of treatment.

EPA's cost estimate projected a cost of compliance for being able to reduce discharges from waste water treatment plants to a level for TN to $3 \mathrm{mg} / \mathrm{L}$ and for TP to $1 \mathrm{mg} / \mathrm{L}$. These treatment levels were far above what its own rule required. In actuality, EPA never did an accurate estimate of what expense its rule criteria would necessitate. It apparently recognized the technological limits of existing treatment facilities and did a cost estimate based on that, not what their rule required.[14]

Thus, it can be seen that EPA's proposed limits appeared to exceed what was technically possible to achieve, in even the most effective treatment processes in use. Naturally, this stimulated a strong response from those utilities. Under part of the CWA, EPA is not supposed to adopt standards which are impossible to achieve. When EPA attempts to require a facility to exceed the "best available practicable control technology" it exceeds its powers. In such a case, where it attempts to require a higher standard, it violates 33 U.S.C. $\S 1311$.
Legal challenges to EPA's rule were filed in U.S. District Court, Northern District of Florida. The consolidated cases were assigned to Judge Robert Hinkle.

\section{Challenges to Federal Rules}

Unlike most court cases, which are determined by the submission of evidence and testimony, legal challenges to Federal rules are determined solely by the record in existence when the rule was adopted. In other words, the documents created by EPA prior to the final action and comments by the public constitute the entire record upon which the rule is based and constitute the only basis to support a challenge to the proposed rule. The submission of testimony and exhibits to the Court is rarely allowed in such proceedings. Only the pre-existing written record is before the reviewing Court.

This process is summarized as follows:

Judicial review of agency action is limited to the administrative records at the time action was taken. 5 U.S.C. $\S 706$ (courts are to review the whole record or those parts cited by a party). The task of the reviewing court is to apply the appropriate APA standard of review, 5 U.S.C. $\S 706$, to the agency decision based on the record the agency presents to the reviewing court. Florida Power \& Light Co. v. Lorion, 470 U.S. 729, $743-44$ (1985). The Supreme Court has emphasized that "the focal point for judicial review should be the administrative record already in existence, not some new record made initially in the reviewing court." Camp v. Pitts, 411 U.S. 138, 142 (1973).

Thus, for the numerous parties that filed a legal challenge to this EPA rule, the basis of their arguments was limited to what was contained in the existing written record. This record also included EPA's responses to comments. [15][16] Additionally, EPA's rules, like other Federal Agency actions, are given a great degree of deference by the courts.

None of the challengers disputed the contention that excessive nutrients can create eutrophication of affected waters. Their impacts are manifested by algae blooms. The above referenced EPA publication describes the effects of over-enrichment as:

Low dissolved oxygen, fish kills, murky water, and depletion of desirable flora and fauna. In addition, the increase in algae and turbidity increases the need to chlorinate drinking water, which, in turn, leads to higher levels of disinfection by-products that have been shown to increase the risk of cancer. Excessive amounts of nutrients can also stimulate the activity of microbes, such as Pfisteria, which may be harmful to human health. 


\section{The Court Hearing}

In January 2012, U.S. District Court Judge Hinkle heard argument from all challengers to EPA's rule. The courtroom was filled by a total of approximately 30 attorneys. Arguments were limited to 5 minutes per attorney. Although these arguments were varied and addressed different parts of the rule, one issue resonated with Judge Hinkle.

While the effects of over-nutrification were well documented, (eutrophication) there is a corresponding opposite condition. That is known as an oligotrophic waterbody. That situation describes a water body which is deficient in nutrients.

Unlike other pollutants, nutrients are essential for life to exist. Nutrients are harmful to aquatic life and water quality only when they exceed appropriate levels. Where natural waterbodies are low in nutrients, there will be a limited diversity of biota and a stressful condition on the viability of fish, aquatic plants, and other wildlife. Thus, Judge Hinkle determined that EPA's rules, and the record in support of these effluent standards, were not adequately supported by sufficient data to demonstrate that its numeric discharge limits were appropriate to prevent harmful impacts. In other words, EPA, by using its reference approach, which utilized data from existing streams to set discharge limits, was based on an unfounded assumption that any higher concentrations would be harmful.

The idea that in order to be considered a pollutant a substance (or a concentration of it) must be harmful in order to be a "pollutant" was addressed by the U.S. Supreme Court in 1966 in United States v. Standard Oil Company, 384 U.S. 224 (1966). That case involved the prosecution of an owner of a barge that accidentally discharged aviation fuel into the St. Johns River, in north Florida. The prosecution was brought under the Rivers and Harbors Act, 33 U.S.C. $§ 407$, which forbade the discharge of "any refuse matter ... in a navigable water." (emphasis added.) At that time, the Clean Water Act (1972) had yet to be adopted.

The barge owner argued that the gasoline was a commercially valuable product, not "refuse." Since "refuse" was the controlling term for any forbidden substance discharged into the navigable water, the company argued its discharge did not violate the Act. The Supreme Court disagreed. It found the purpose of the act was to prevent harm to the nation's waters. Among other things, the Court stated: "This case comes to us at a time in this Nation's history when there is greater concern than ever over pollution - one of the main threats to our free-flowing rivers and to our lakes as well." (p. 225) Further, it determined "Oil is oil and whether it is usable or not by industrial standards it has the same deleterious effect on our waterways. In either case, its presence in our rivers and harbors is both a menace to navigation and a pollutant." (p. 226)
Thus, as determined by the U.S. Supreme Court, any substance which, in some concentrations, will be harmful to waterbodies is a pollutant. Yet the contrary must also be true, any such discharge which is harmless or beneficial is not a pollutant. Since the EPA rule adoption record for this rule did not demonstrate its stringent nutrient limits were appropriate to prevent degradation of such waters, the Florida District Court found EPA's proposed standards to be invalid.

\section{Decision of the Court}

On February 18, 2012, U.S. District Court Judge Hinkle issued an 86 page order on the challenge to the EPA Numeric Nutrient Standards. He determined the EPA Administrator's "necessity determination," that it had to adopt a numeric standard for Florida, was valid. However, he found the bulk of the EPAs rule invalid. Based on arguments presented by this author, he determined there were significant flaws in EPA's approach and methodology. Specifically, he found EPA had established no basis in the voluminous record to indicate that the standards for streams and rivers were necessary to prevent harmful impacts to those waters. The inherent assumption in the EPA rule - that any change in flora and fauna, which might occur through the addition of more nutrients would be harmful, was found to be impermissible, arbitrary and capricious. EPA's position and justification of the Rule on that basis was found to be inadequate. He determined that EPA was misguided in its approach, which sought to prevent any man-induced changes in flora and fauna through these rules. It was necessary, Judge Hinkle found, that EPA must have determined that exceedances of its nutrient limits would be harmful, which it failed to address.

The rationale for the Court's decision is explained in the following excerpt from its February 18, 2012 Order: Identifying the actual target at which the Administrator was aiming is difficult. The Administrator says that here, as with the rest of the rule, the goal was to translate Florida's existing narrative criterion: "nutrient concentrations of a body of water [must not] be altered so as to cause an imbalance in natural populations of aquatic flora or fauna." Fla. Admin. Code r. 62-302.530(47)(b). This was an appropriate goal. In order to pursue this goal, the right target was a criterion that would identify a harmful increase in a nutrient level-an increase that, in the language of Florida's narrative criterion, would create an "imbalance" in flora or fauna. This is the target the Administrator was shooting at in her initial approach using models and field studies.

But when she turned to the sample-set approach, the Administrator apparently changed the target, shooting not for a criterion that would identify a 
harmful increase in a nutrient level, but a criterion that would identify any increase in a nutrient level. As all parties seem to agree, any increase in nutrients causes a change in flora and fauna, but not every increase in nutrients causes a harmful change in flora and fauna. There is a substantial difference, then, between a criterion designed to identify a harmful increase in a nutrient level, on the one hand, and a criterion designed to identify any increase in a nutrient level, on the other hand.

The conclusion that the Administrator aimed at the wrong target draws support from three sources. First, the Administrator asserted at oral argument that the Florida narrative criterion applies to any change in flora and fauna and that Florida so interprets the criterion. That is incorrect. But if, in devising the stream criteria, the Administrator's understanding was the same as asserted at oral argument, that is, if the Administrator set out to translate the wrong thing, she aimed at the wrong target.

Second, as discussed in more detail later in this opinion, for a stream entering a lake that is in compliance with the lake criteria and for which a model has not been constructed, the Administrator set the downstream-protection criteria or DPVs at ambient conditions at the point where the stream enters the lake. The use of unadjusted ambient conditions makes clear that at least for that purpose, the Administrator was shooting at a target intended to identify any change in nutrient levels, not just a harmful change. That this was the Administrator's target there - the only other part of the rule not based on modeling or field studies - suggests that this was also the Administrator's target for the stream criteria.

Third, and most important, the Administrator set the stream criteria based on naturally occurring ambient conditions - those that exist now, on average, in unimpaired streams - without building in an adjustment for increases in nutrients that are not harmful. Instead, a stream is deemed impaired-in four of the regions - if a nutrient level exceeds that of $90 \%$ of the sample set. This is the criterion even though the other $10 \%$ are apparently unimpaired at a higher nutrient level. The Administrator explained the $90 \%$ mark in terms that make sense if the target is a criterion that identifies any increase in nutrients and thus any change in flora and fauna: one can say with some confidence that a stream with a nutrient level that exceeds that of $90 \%$ of the sample set probably has suffered an increase in nutrients and a resulting change in flora and fauna. But if the target is a criterion that identifies a harmful increase in nutrients, there is an unexplained disconnect. The Administrator has not explained how the $90 \%$ mark correlates with a harmful increase in nutrients. It may well be that there is a sufficient correlation. An experienced environmental scientist might be able to conclude, as a matter of sound scientific judgment, that above the 90th percentile, harmful change is likely. But a reviewing court cannot properly make its own analysis of an issue that the agency did not address. Nor can a court "supply a reasoned basis for the agency's action that the agency itself has not given." Bowman Transp., Inc. v. Ark.-Best Freight Sys., Inc., 419 U.S. 281, 285-86 (1974). The stream criteria thus cannot be upheld as an appropriate means of identifying nutrient levels that will cause harmful effects.

To be sure, the Administrator was not required to aim for the same target as the state. Instead, the Administrator's job was to adopt a "revised or new standard" meeting the Clean Water Act's requirements. If the Administrator had concluded that nutrient criteria should be designed to block any change in flora or fauna, not just an "imbalance" as the state defines it, the conclusion would be subject to arbitrary-or-capricious review, but the fact that the Administrator disagreed with the state would not be fatal.

This does not, however, save the stream criteria. The Administrator did not purport to exercise her judgment in deciding that criteria should be designed to block any increase in flora and fauna. She purported instead only to defer to the state's judgment - and the state never concluded that any increase in flora and fauna is harmful or that water-quality criteria should be designed on this basis. And even if the Administrator in fact concluded that criteria should be designed to block any increase in flora and fauna, the rule still would fall, because the Administrator did not adequately explain the decision. If there is a basis in sound science for disapproving any change in flora and fauna - and thus any increase in nutrients - the Administrator did not cite it.

The Administrator's adoption of the stream criteria, with no further explanation than given, was arbitrary or capricious.

Thus, the Court's decision was not determined by an evaluation of data submitted by the entities challenging EPA's methodology. EPA's lack of a demonstrated cause and effect relationship between the limits of its allowable discharge concentrations and the environmental impact on the waterbodies from such impacts were found to be lacking. This is why the Judge found EPA's criteria to be "arbitrary or capricious." 


\section{Florida's New Nutrient Rule}

Although the opposition forces to EPAs efforts were gratified by this decision, it did not mean EPA could not re-attempt to justify its rule or begin again to start a new rule process. To avoid such a result, Florida decided to adopt its own numeric nutrient discharge rule, in order to satisfy EPA and avoid further controversy. On November 30, 2012, EPA officially accepted and approved DEP's new Numeric Nutrient Rule. EPA's announcement stated:

EPA has approved the Florida Department of Environmental Protection's (FDEP) rules to protect Florida's waterways from excess nitrogen and phosphorus. These pollutants, called "nutrients," cause algal blooms, contaminate drinking water supplies and are among the largest contributors to water quality problems in Florida. FDEP's rules establish numeric limits on the amount of nutrient pollution allowed in statewide springs, lakes, streams and some estuaries. Following a thorough review of the state's adopted rules and supporting documents, EPA determined they are consistent with the requirements of the Clean Water Act and applicable federal regulations for the water bodies they cover.

(Emphasis added).

Thus, Florida now has its own Nutrient rule, expressed in numeric concentrations and discharge limits. It still retains its narrative rule but now also has a numeric standard to implement the narrative criteria. DEP's numeric nutrient rule is complex. The full text can be found at Chapter 62-302.531, Florida Administrative Code, titled: "Numeric Nutrient Interpretations of Narrative Nutrient Criteria."

When DEP published notice of its intention to adopt its own numeric standard, Earthjustice, the same entity that sued EPA to require it to adopt a rule for Florida, challenged DEP's proposed rule as being inadequate.

Unlike the challenges to Federal Rules, Florida has a different process to hear challenges to state rules. Such cases are considered by Administrative Law Judges, who have the power to declare them to be invalid. The Florida Wildlife Federation and Earthjustice filed such a challenge. Again, such proceedings are conducted differently than in U.S. District Court in that each party has the opportunity to call witnesses, present other evidence and make detailed presentations. As mentioned above, the Federal Judicial process is much more limited when it comes to adjudication of the validity of Federal Rules. Also, unlike the Federal system, in Florida, proposed rules have no presumption of validity.

The petitioners against Florida's rule argued that those criteria were insufficient to control chronic algae blooms and did not adequately protect its waters and the public health. However, the Administrative Law Judge determined Florida's proposed criteria were within its range of allowable discretion. He upheld the proposed rule, which thereafter went into effect.

\section{Effect of Florida's New Rule}

This author, working with water quality experts and consultants, has had occasions to determine whether applicants for discharge permits would be in compliance with DEP's Numeric Nutrient Rule. The consensus opinions are that the rule is very difficult to understand and apply. Further, the sampling requirements for the receiving waters are expensive and very tedious in time requirements.

It is also ironic that after such extensive litigation and deliberation, DEP's present Numeric Nutrient Rule is largely ignored and rarely applied by State regulators. Stormwater discharge permits, residential and development permits (Environmental Resource Permits), are commonly reviewed through a criteria which measures the volume of retention a project provides and not specifically whether the discharge will comply with the Numeric Nutrient Rule. These criteria are in a publication titled Environmental Resource Permit Applicant's Handbook, Volumes I and II. This Handbook has been adopted by rule 62-330.010, Florida Administrative Code. This rule creates a rebuttable presumption that if the criteria in this Handbook are followed, "surface water standards" are presumed to be met. The Handbook does not specifically refer to the requirement to comply with DEP's new Numeric Nutrient Rule. EPA's acceptance of Florida's Numeric Nutrient Rule on November 30, 2012, was presumably based on its assumption that Florida would apply those criteria in all permit applications where water quality standards were applicable to the decision on the application. However, that is not the present situation. Permits for discharges into State waters appear, in practice, unchanged from what existed before EPA's decision, on January 14, 2009, that Florida must adopt objective standards for nutrients. Although Florida has adopted such standards and criteria "on paper," in reality, little has changed.

\section{Conclusions}

Legal challenges to proposed Federal Rules are not determined in a manner that follows the typical process of courtroom proceedings. It is a common expectation that a litigant in a legal proceeding will have the opportunity to call witnesses and present other evidence before the Court. Because the court decisions on Federal rule cases are based only on the agency record, it is vital that challengers submit comments to the agency to be included in the "record." Further, the agency rationale for the rule must be closely examined and the factual basis for the agency decision should be subject to a very critical analysis. 
The idea that a water quality standard must be justified on whether its criteria is based on reasonable scientific analysis of potential harmful effects is not a new concept. Potable water standards are developed in this fashion and rely on toxicology to determine safe levels or tolerances. However, this case illustrates there must be a valid basis for water quality criteria. Assumptions are not adequate to justify a discharge limitation. The EPA was not successful in this regulatory attempt because it made a fundamental assumption as to what limits on nutrient discharges were necessary to protect Florida's waters from the impacts of over-nutrification. That assumption was crucial to the rule development process, but was found to provide no rational support for the water quality criteria EPA selected. The absence of a record foundation that exceedances of EPA's tolerances would be harmful to the receiving waters was fatal to the Rule's validity.

\section{REFERENCES}

[1] Fernald, E.; Patton, D. "Water Resources Atlas of the State of Florida.” Florida State University Press. 1984.

[2] Borkowski, W.; and Childs, D. Memorandum to Florida Water Environmental Association: "EPA moves to Extend Consent Decree Deadlines. November 26, 2012.

[3] Public Notice, U.S. Environmental Protection Agency, Region 4, Water Protection Division, Atlanta, GA: "NOTICE OF AVAILABILITY. PROPOSED MAXIMUM DAILY LOADS (TMDLS). FOR WATERS AND POLLUTANTS IN THE STATE OF FLORIDA." November 30, 2012. James D. Giattina, Director, Water Protection Division.

[4] Memorandum Opinion, Civil Action No. 1:12-cv-775. Virginia Dept. of Transportation v. EPA, U.S. District Court, Eastern District of Virginia. January 3, 2013. Liam O'Grady, U.S. District Judge.

[5] Federal Register, Vol. 75, No. 16. January 26, 2010. U.S. Environmental Protection Agency. "Proposed Rules." 40 C.F.R., Part 131. "Water Quality Standards for the State of Florida's Lake and Flowing Waters"
[6] Griffith, G.; Canfield, D.; Horsburgh, C.; Omerink, J. "Lakes Regions of Florida." U.S. Environmental Protection Agency. August 15, 1997. (EPA/R-97/127).

[7] "Biological Nutrient Removal Process and Costs." U.S. Environmental Protection Agency, Office of Water. June 2007. (EPA-823/R-07/002).

[8] Dodds, W.K.; Blair, J.M.; Henebry, G.M; Keolliker, J.K.; Ramundo, R.; and Tate, C.M. "Nitrogen Transport from Tallgrass Prairie Watersheds." 1996. Journal of Environmental Quality. (25:973-981).

[9] Chapter 4 of Appendix B to Final EPA Numeric Nutrient Rule for Florida. "Potential Costs for Municipal Wastewater Sources".

[10] Joint Notice to the Court of Extension of Consent Decree Deadline. Fla. Wildlife Federation, Inc. v. Lisa Jackson, EPA. Case No. 4:09-cv-00324RH-WCS. U.S. District Court, Northern District of Florida, September 30, 2011

[11] Steinbrecher, P.; Childs, D. "New EPA Numeric Criteria Rule Raises Storm of Protest in Florida.” April 2011. Florida Water Resources Journal.

[12] Hammond, D.; Durbin, D.; Robbins, Kristan N.M.; and MacNair, Doug. "NUMERIC NUTRIENT CRITERIA IN FLORIDA. HOW IT HAPPENED AND WHAT IT MEANS FOR GEORGIA." Proceedings of the 2011 Georgia Water Resources Conference, April 11-13, 2011 at the University of Georgia.

[13] Necessity Determination for Imposition of New Water Quality Standards for Nutrients in Florida. Letter from Benjamin Grumbles, Asst. Administrator, U.S. Environmental Protection Agency, to Michael Sole, Secretary, Florida Department of Environmental Regulation. January 14, 2009.

[14] Cardno Entrix. "Economic Analysis of Proposed Numeric Nutrient Criteria for Florida. Prepared for Water Quality Coalition. November 2010

[15] U.S. Environmental Protection Agency. Response to Public Comments regarding Proposed Numeric Nutrient Criteria for the State of Florida's Lakes and Flowing Waters. Docket No. EPA-HQ-OW-2009-0596. November 14, 2010.

[16] U.S. Environmental Protection Agency. "Guidance on Systematic Planning Using the Data Quality Objectives Process." Office of Environmental Information. February 2006. (EPA/240/B-06/001). 